\title{
A Local Counter-Discourse against National Education Problems: Postcolonial Reading of Andrea Hirata's Laskar Pelangi
}

\author{
Andreas Akun \\ English Department, Faculty of Language and Culture, Binus University, \\ Kemanggisan Ilir III No. 45, Palmerah, Jakarta 11480, \\ West Java, Indonesia \\ e-mail: akun@binus.edu; and.akun@gmail.com
}

\begin{abstract}
This study aims at exploring postcolonial themes raised by Andrea Hirata's Laskar Pelangi (Rainbow Warriors). Specifically, it will reveal the characteristics of hybridity found in the novel that prove this literary work may be categorized as postcolonial writing despite the fact that western or white colonialism has no impact or trace at all in the novel. Furthermore, the study will prove that this national novel with its very local issues is a counter discourse, a subversive tool for the writer to criticize the domination of certain groups upon their own marginal fellows. Education, as a global issue, is one Indonesian national and typical ironic problem teased through local culture and even mysticism in this novel.
\end{abstract}

Key words: post colonialism, counter discourse, hybridity, education, mysticism

Education in Indonesia has been problematic for such a long time. There are two big poles playing roles in the ups and downs of Indonesian education: public or government and private schools. Mostly, government schools do not experience problems faced by private schools such as the number of students registering at the schools as depicted in the novel. Further, the problems do not lie on the dichotomy of public-private schools, but on the discrepancy among the private schools themselves. In terms of domination and discrimination, incongruity among private schools is so apparent and immense.

Laskar Pelangi (Rainbow Warriors) -henceforth LP-- is Andrea Hirata's debut and memoir picturing the discrepancy among private schools and the sad irony of local education, in a naturally rich island: 
Belitung. Published in 2005, the novel has got much attention from many people through printed and electronic media, becoming a reference to education matters, inspiring some to revisit and discuss Indonesian present education problems. Set in a small and remote island Belitong, specifically a smaller area Gantong, in South Sumatera (now Bangka Belitung Province), the story recounts the struggle of ten high-spirited village students along with their devoted teacher and headmaster. The novel centers around Ikal (the narrator, also the author), Lintang (the genius) and Mahar (the artist). Typical local issues such as social yawning gaps between aborigine (the original Belitong inhabitants) and the new comers (PN Timah people or Government Tin Mining Company people) and education gap between marginal local Muhammadiyah school and dominating PN Timah school are strongly and satirically criticized, and to some extent deconstructed in the progress of the story. The author makes use of some local cultures and even mysticism to tease the domination of certain groups upon their own marginal fellows and the everlasting problems in local and national education.

This writing will simply explore two aspects: first, why this novel may be categorized as postcolonial writing and second, how this piece of writing may be considered as a counter discourse in the mainstream of Indonesian writings and education problems. As for me, this study is my personal revisit to my hometown Belitung as an original inhabitant and to Sanata Dharma with its Rafil as an alumnus.

According to Barry (2009), postcolonial reading of certain literary works will need to involve at least four characteristics: first, a conscious understanding of representations of the non-European in literature as alien or decadent 'Other'; second, an avoidance of writing in the colonizers' language for it is everlastingly contaminated and to write using it means to accept with consent the colonial structure; third, an emphasis on doubled, hybrid or unstable identity; and last, the stress on cross-cultural interactions. In connection with the above characteristics and the degree of dependence/independence, postcolonial writings fall into three categories: the adopt phase (an unquestioning acceptance of colonial model), the adapt phase (an adaptation or partial intervention) and the adept phase (a declaration of cultural independence from the colonial model) (pp. 189190). Aveling (1993) reviews that there are three important features of all postcolonial writing: the silencing and marginalizing of the postcolonial voice by the imperial centre, the abrogation of the imperial centre within 
the text, and the active appropriation of the language and culture of the centre.

In this study, it is important to redefine who the colonizer is. Due to the object of this study, that is non-English fiction, and then I will refer to Aveling's writing Non-English Postcolonial Fiction? The Malaysian Case (1993) to extend post colonialism to literary works written not in English, in this case in Indonesian, and to redefine that the colonizer in this context can be any group outside the white European, in this case fellow colonizer even coming from the same country. This, in my view, is possible because position in colonization can be ambiguous. Tiffin gives an example of this in Australian case: "Moreover, such a model can account for the ambiguous position of say, white Australians, who, though still colonized by Europe and European ideas, are themselves the continuing colonizers of the original inhabitants” (Ashcroft, Griffiths, \& Tiffin, 2004, p. 96). The same case happens to white American domination over the native Indian while being dominated by the British.

The next part of this study will be focused on the exploration of LP as a counter discourse. Ashcroft, Griffiths, and Tiffin (2007) have defined Counter Discourse as "theory and practice of symbolic resistance". They stated that it is a term coined by Richard Terdiman referring to his examination on French literature focusing on:

... the means of producing genuine change against the 'capacity of established discourses to ignore or absorb would-be subversion ... the confrontation between constituted reality and its subversion' as 'the very locus at which cultural and historical change occur. . . . This term has been adopted by post-colonial critics to describe the complex ways in which challenges to a dominant or established discourse (specifically those of the imperial centre) might be mounted from the periphery, always recognizing the powerful 'absorptive capacity' of imperial and neo-imperial discourses (50).

Counter discourse is then an exertion practiced by the marginal group to destabilize or subvert the overarching domination of the mainstream, dominating group. Ashcroft, Griffiths, and Tiffin, (2004) called this attempt a "subversive maneuver". 
These subversive maneuver . . . are what is characteristic of postcolonial texts, as the subversive is characteristic of post-colonial discourse in general. Post-colonial literatures/cultures are thus constituted in counter-discursive rather than homologous practices, and they offer 'fields' of counter-discursive strategies to the dominant discourse. The operation of post-colonial counter-discourse is dynamic, not static: it does not seek to subvert the dominant with a view to taking its place, but . . . to evolve textual strategies which continually 'consume' their 'own biases' . . . at the same time as they expose and erode those of the dominant discourse. . . (pp. 95-96).

It is clear that these counter-discursive strategies are in a way active and forceful, but they do not aim at overtaking the dominant power or inverting the position. As the name indicates, it is a strategy, developed through textual discourse as to depict clearly in a teasing way the weaknesses or biases of the colonizing, dominating power, in the hope of eroding, or at least showing the extension of dominant supremacy. Being deconstructive and subversive can be an effective strategy to question the domination over the marginal group for future transformations.

Ashcroft (2001) has stressed the quality of being resistant and transformative as the characteristics of counter-discourse:

Yet theirs is a resistance which is explicitly transformative. For they do not simply respond to the canonical texts but attempt to re-write them in such a way that their overweening cultural assumptions become exposed and subverted. In this way they 'establish an oppositional, disidentificatory voice within the sovereign domain of the discourse of colonialism'... Because of its function within the dominant discourse, canonical counter-discourse is a very clear demonstration of the link between resistance and transformation. For although the intertextuality of the canonical texts is crucial, it is no longer their centrality or 'greatness' which dominates, no longer their revelation of the 'universal human condition', but the newly revealed cultural horizons of their hybrid and transformative 'counters' (pp. 33-34).

Ashcroft emphasized the importance of resistance nature of the discourse to be transformative in effect. This resistance is expressed through the freshly, not necessarily universal views of the crossed-mixed quality of the 
existing cultural expressions. Therefore, this new and hybrid counter discourse can only voice the subversion if it is resistant in nature towards the hegemonic domination of the mainstream discursive power.

Furthermore, Paryz (2006) quoted Tiffin that "decolonialization is process, not arrival; it invokes an ongoing dialectic between hegemonic centrist systems and peripheral subversion of them; between European or British discourses and their post-colonial dis/mantling” (p. 567). So, the counter discursive strategy is an on going process, not the end result. It is some kind of dialog consisting of resistance and subversion from the dominated, marginal group (normally bigger in number) towards the dominating, central power to tease its hegemonic domination.

And hence the goal of this study is to trace and reveal the above characteristics of counter-discursive strategies with their dynamism, resistance and transformation in LP.

\section{METHODS}

This is a library research and the data are mainly taken from LP novel. Postcolonial approach, specifically counter-discourse concept, is applied in the textual study of the novel. Just as the strategy from counter discourse, deconstructive and subversive reading will be done in this study by decentralizing the center (dominant discourse power) and empowering (centralizing) the peripheral marginal group.

\section{FINDINGS AND DISCUSSION}

There are two main discussions essential to this study: the elaboration of cross cultural interaction found in the novel and the revelation of the counter discursive strategies employed in the work through the author's deconstructive way of perceiving the reality.

\section{Cross Cultural Interaction}

The hybrid identity and cross-cultural interaction can noticeably be seen in the ten rainbow warriors with all their happy struggling childhood actions, dreams and imaginations. First of all, there is a strong description on the relationship between Ikal (a local boy with his Malay background, pp. 162-163) and A Ling ( a little girl with her Chinese background, pp. 35- 
36). This solid, but almost impossible relationship may be exposed through the poems they write. Who is Ikal? A Ling has her uneasy perspective:

\section{Rindu}

Cinta benar-benar telah menyusahkanku

Ketika kita saling memandang saat sembahyang rebut

Malamnya aku tak bisa tidur karena wajahmu tak mau pergi dari kamarku

Kepalaku pusing sejak itu ...

Siapa dirimu?

Yang berani merusak tidur dan selera makanku?

Yang membuatku melamun sepanjang waktu?

Kamu tak lebih dari seorang anak muda pengganggu!

Namun ingin kukatakan padamu

Setiap malam aku bersyukur kita telah bertemu

Karena hanya padamu, aku akan merasa rindu ...

A Ling (pp. 280-1).

\section{(Longing)}

Love has truly bothered me

When we stared at each other during the sembahyang rebut

That night I couldn't sleep because your face wouldn't leave from my room

I had a headache ever since ...

Who were you?

That dared to spoil my sleep and appetite?

That made me have daydreams all day long?

You were not more than a disturbing young boy!

But I wished to tell you

Every night I was thankful that we'd met

Cause only for you, I felt the longings ...

Beyond her attraction, love and longings to Ikal, A Ling somehow feels problematic due to her background (p. 253); however, this interaction dominantly shows the possibility of a mixed, doubled relationship rather 
than its hindrance. What about Ikal? Who is A Ling in his experience? Let's have a look at his poem:

\title{
Jauh Tinggi
}

A Ling, hari ini aku mendaki Gunung Selumar

Tinggi, tinggi sekali, sampai ke puncaknya

Hanya untuk melihat atap rumahmu

Hatiku damai rasanya (p. 292).

\section{(So High)}

\author{
A Ling, today I climbed mount Selumar \\ So, so high, up to the top \\ Only to see the roof of your house \\ I felt so peaceful
}

Similarly, Ikal's strong attraction to A Ling is problematic due to the distance (difference in their ethnic background) that blocks their relationship. He climbs the mountain just to see the roof of A Ling's house because he cannot visit her house directly. But it does not stop them to interact and to feel the peace and longing. The meaningful relationship is stressed more than the difficulties.

Secondly, the relationship between Mahar with his Belitong, Malay, artistic background and A Kiong with his real Chinese, Kong $\mathrm{Hu} \mathrm{Cu}$ background (p. 68) shows another blended relationship. A Kiong is a loyal follower of Mahar (p. 161). This possibility is strengthened by the fact that A Kiong goes to a Moslem school and finally turns into a Moslem, a very rare chance in Belitung circumstance.

Thirdly, how Sawang people (nomadic people who live in boats, pp. 163-165) give meaning to a local Chinese tradition called sembahyang rebut or Chiong Si Ku (Chinese tradition of seizing donated stuff as a part of yearly ritual of burning/driving away the evil side of human beings and their bad luck, pp. 257-264) also describes an element of cross-cultural interaction. Sawang people are the superstar (p. 262) of this religious, meaningful, artful and charming tradition. They don't care much about Thai Tse Ya, the symbolic figure of devil/ghost king, or other valuable stuff, but the red cloth called fung $p u$ which constitutes the symbolic supremacy of the tradition and may be traded with a lot of money. 
Moreover, this tradition is accompanied with the local entertainment such as panjat pinang (climbing palm trees to seize everyday stuff), circus or Malay orchestra, showing the interaction and becoming the gathering medium of four local sub ethnics: the Chinese (Tionghoa), the Malay, the Sawang and the island people with sarong (p. 259).

Fourthly, the title Laskar Pelangi itself indicates a mixed identity from different backgrounds. Pelangi (rainbow) is beautiful only if there are more than one color, signifying the multicultural 10 students with their different ethnic backgrounds. Laskar (warrior) signifies a fight against their marginality, some kind of counter-discursive strategy against the mainstream that will be discussed in the next section.

Lastly, Flo is a character used by Hirata to represent the interaction between the two different groups: the poor local and the elite comer. Flo (pp. 43-45) is not happy with all her luxurious life, family, and school. She escapes all of those lavish background, finding a true meaning of life and friendship with the poor natural rainbow warrior, especially Mahar. The interaction is somehow important because she is the only bridge that connects the two dissimilar groups. Flo also has an ambiguous identity, she is the symbol of fluid interaction of gender: a little girl with boyish attitudes (p. 47). More than that, Flo's family is another symbol of confusing position because her father is the only Belitong original Malay who has the elite position (pp. 46-47), giving him a blurred position as a local or invader.

\section{Counter Discourse}

In connection with domination, specially connected with education, the main issue explored in LP is the contact between the local marginalized group (though bigger in number, represented by the rainbow warriors) and the mainstream, invading and dominating group (represented by PN Timah). The domination is so intense that the local people feel alienated from their own homeland. For example, the people who live in the gedong (mansion) have strange names such as Susilo, Cokro, Ivonne, Setiawan or Kuntoro without the local names such as Muas, Jamali, Sa'indum, Ramli or Mahader (p. 42). However, Hirata describes the marginalized local group as having more power to fight back the giant domination of the invader. The following part shows how the local is placed as being able to 
destabilize or subvert the domination, a counter-discursive strategy developed by the novelist.

The first counter discourse is seen in the way Hirata presents the marginal poor, traditional and almost closed Muhammadiyah elementary school as overpowering the elite, rich, and modern PN Timah school and the people. The giant power of PN Timah is symbolized by The Tower of Babel (pp. 35-40), Gedong (luxurious house, mansion, pp. 41-48) with elite schools called Center of Excellence (pp. 57-61). PN Timah's being elite is a heritage from the Dutch colonialism (pp. 40, 43), passed down to them with the support of the local government through good upeti (p. 39). Now the colonial domination is not from the European countries (i.e. The Dutch) but from their own fellows. The extreme gap between the local and PN Timah people is obvious in the printed and repeated notice by PN Timah: "DILARANG MASUK BAGI YANG TIDAK MEMILIKI HAK" (No Trespassing for those having no right, pp. 36, 43, 58, 426).

However, all dominating excellence is destroyed by the tiny local group in some chances. Hirata inverts the situation when they are faced in an academic competition, for example the Cerdas Cermat (academic competition for elementary school students) when the local students, represented by the genius Lintang (p. 363), embarrass the elite students, even their arrogant teacher, Mr. Zulfikar (pp. 376-7). Before that, the local students have proved their existence by winning the annually held carnival for celebrating the country's independence. This time, represented by Mahar, the genius artistically talented student, they defeat the glamorous elite students by their, once again, simple, natural but culturally rich parade.

The second counter is presented when Hirata describes the figure of a teacher, an important character that constitutes the spirit root of the story. The author provides a total contrast between the local teachers (Bu Mus and Pak Harfan) and the elite school teachers (Bu Frischa and Pak Zulfikar). The local teachers are depicted as having strong qualities such as their loyalty, acceptance, devoutness, and heavenly spirit, while the elite teachers are pictured as arrogant (Drs. Congkak, p. 377), humiliating, unnatural intimidating and antagonistic (pp. 60-61).

The third counter-discursive strategy is developed through the deconstruction of the local mainstream belief in a legendary myth named Tuk Bayan Tula. This third strategy is applied to further criticize not only the elite group, but also the education problems in this country as a whole through the fun use of mysticism. The author juxtaposes the famous local respected legend of Tuk Bayan Tula, an extraordinarily powerful mythical 
and mystical figure (also represented by a group called Societiet de Limpai, with Mahar as the leader) with school scientific matters. The description of Tuk Bayan Tula's response to the school children is beyond expectation, owing to the fact that in a Belitung's mainstream mystical figure it is just impossible that this legendary and imaginary figure is literate and formally educated. So when Tula writes "INILAH PESAN TUK-BAYAN-TULA UNTUK KALIAN BERDUA, KALAU INGIN LULUS UJIAN: BUKA $B U K U, B E L A J A R ! !$ ” (Here is Tuk-Bayan-Tula's memo for both of you: if you wish to pass the exam, open your book, study!!” p. 424), it is merely a discourse developed by the author to deal with the education problems. This memo is clearly criticizing the national education with its national examination, reminding teachers and students, that the only right way to succeed is to go the right hard way i.e. study. Other uses of myth versus science discourse are seen in the Jemang Hantu (Ghost Jemang) case (p. 390) and the myth of Gua Gambar (Picture Cave, pp. 393-399) and Bodenga, the crocodile man (pp. 87-102). All possibilities are represented by Mahar, an eccentric character, a great story teller who stands in the grey area, between imagination and reality (p. 393), between the myth and the modern science. His stories about Jemang Hantu or Gua Gambar and his responses are similar to Tuk Bayan Tula, giving the readers unexpected shock by the presentation of close interaction between the traditional myth and modern science, then becoming a strategy to counter the mainstream belief. Bodenga himself is presented as mysterious, mystical, having no identity at all (p. 91) but also kindhearted.

The fourth counter discourse is revealed through viewing certain ethnic groups with a different, deconstructive perspective. The Tionghoa (Chinese) people for example are differently described in this story in opposition to the common view. They are depicted with more positive images (remember how are they, as victims, dominantly viewed through 1998 chaos?) as older inhabitant of the island, kindhearted, down to earth, hardworking and poor (pp. 35-37). The Chinese are also described as having similar marginalized position as the other local people; all of them live outside the Tembok (great wall) or Gedong, that they have their own Belitong Great Wall (in analogy with the Jinchanying/ China Great Wall, pp. 36, 432).

The fifth counter, I believe, is clear in the maintaining use of minor local words. Hirata keeps the local words intentionally, providing strength to his overall work, proving that the minor/marginal is somehow symbolically strong enough to destabilize the mainstream. Why, for 
example, does Hirata use Belitong (p. 4) instead of its official Belitung? The sense of locality is paramount in this case for it gives the soul to his discourse to deconstruct the domination of the (Indonesian) mainstream, as described previously. Therefore Hirata uses local words such as Gantong, Tanjong Pandan (p. 47), Tanjong Kelumpang, burut (p. 99), lelak, cunghai (p. 11), etc. to give the sense of superior locality.

\section{CONCLUSION}

Laskar Pelangi, through postcolonial perspective, is clearly not merely a story of how struggle or spirit is important to survive the life as a marginal group, but more than that it is about how the minority actually have the potential to fight back ideologically the domination of the mainstream. This is done of course through a different deconstructive view of the postcolonial problems.

Through the above discussion, it is obvious that postcolonial characteristics are found in this work. Elements of hibridity and intercultural interaction are found for instance in Ikal-Aling, Akiong-MaharFlo, Sawang-Malay-Chinese relationships. The relationships are viewed as positive, celebrating, and strengthening. While counter-discursive strategies developed by the author can be traced in the inverted positioning of marginal against the dominating group. The marginal has shockingly been represented as overpowering the dominating group. This is also done through the representation of deconstructive teacher images. Furthermore, the myth and science are teasingly used to criticize the education problems by having, again, shocking responses from mystical and mythical figures such as Tuk Bayan Tula, Bodenga, and Mahar. The other counters are seen in the different perspective on certain ethnic groups such as the Chinese, with their positive images. And finally, the use of language also takes a significant role by the use of minor local words to maintain the ideologically believed hope that the marginal the tiny island with all the marginalized positions may have an opportunity to fight against the superior mainstream and win.

As a whole, I believe that this piece of work is a tool for Hirata to make use of the locality and marginality to subvert the domination of the mainstream power as to invert the position in the hope for better understanding of each other. 


\section{REFERENCES}

Ashcroft, B. (2001). Post-colonial transformation. London: Routledge.

Ashcroft, B., Griffiths, G., \& Tiffin, H. (2007). Post-colonial studies: The key concepts. New York: Routledge.

Ashcroft, B., Griffiths, G., \& Tiffin, H. (2004). The post-colonial reader. New York: Routledge.

Aveling, H. (1993). Non-English postcolonial fiction? The Malaysian case. SPAN: Journal of the South Pacific Association for Commonwealth Literature and Language Studies, 34. Retrieved November 10, 2008, from http://kali.murdoch. edu.au/ cntinuum/litserv/SPAN/34/Aveling.html

Barry, P. (2009). Beginning theory: An introduction to literary and cultural theory. Manchester: Manchester University Press

Hirata, A. (2008). Laskar pelangi. Yogyakarta: Penerbitan Bentang.

Paryz, M. (2006). Beyond the traveler's testimony: Emerson’s English Traits and the construction of postcolonial counter discourse. American Transcendental Quarterly, 20, 565-591. 